\title{
The Influence of Service Quality, Trust and Customer Value on Customer Satisfaction at Gerai Indosat Ooredoo WTC Surabaya (The Study Case of Samsung's Bundling Product Customers)
}

\author{
Eko Wahyu Nugroho ${ }^{1}$, Elok Damayanti ${ }^{2}$, \\ kowahyunugroho@gmail.com ${ }^{1}$, elok.damayanti@narotama.ac.id ${ }^{2}$ \\ Departement of Manajemen, Faculty of Economics and Business, Narotama University \\ Jl. Arief Rachman Hakim 51 Surabaya, Indonesia 60117,2,3
}

\begin{abstract}
The purpose of this research is to find out The Influence of Service Quality, Trust and Customer Value on Customers Satisfaction at Gerai Indosat Ooredoo WTC Surabaya in simultaneously and partially. This Research used quantitative method with 70 respondents of population and samples were collected by giving questionnaires to the customers who have bought Samsung's Bundling Product from Gerai Indosat Ooredoo WTC Surabaya. The data was analyzed used multiple linear regression technique and classic assumption test. The results showed that the hypotheses have effects to Customers's Satisfaction simultaneously and partially.
\end{abstract}

Keywords: service quality, trust, customer value, customer satisfaction

\section{Research Background}

\section{INTRODUCTION}

Indosat Ooredoo, which has become a Samsung business partner by means In essence, technology in Indonesia is now increasingly rapid in marketing its products. Especially on Samsung smartphone technology products from South Korea with the Android operating system. by following the market needs of customers through the design and development of the latest technology and also in product sales in Indonesia. Samsung is one of the largest companies in the world, with product quality that is highly trusted as the most popular product of the people, so it is widely known by the people of Indonesia

In increasing smartphone sales, Samsung cooperates with a number of providers in Indonesia, one of Bundling Product.

Product bundling is a sales strategy that is applied in marketing. Product bundling has the aim of maximizing profits in various types of marketing which are usually done in the field of research in the form of products and prices. This phenomenon can benefit customers who will buy Samsung mobile phones through Indosat Ooredoo outlets, especially because pulses and data packages have become basic needs.

While running the product bundling program, sales of Samsung mobile phones from various product variants available at the Indosat Ooredoo Outlet have fluctuated. This shows that the public and customers are very interested in the sales program run by Samsung with Indosat Oeredo in product bundling.

Tabel 1.1 Perkembangan Penjualan Product Bundling

Periode Juli 2018 - Maret 2019

\begin{tabular}{|l|l|l|}
\hline Bulan & $\begin{array}{l}\text { Volume Penjualan } \\
\text { Bundling } \\
\text { (dalam unit/Rp.) }\end{array}$ & Keterangan \\
\hline Juli & 18 & \\
Agustus & 22 & Naik \\
September & 10 & Turun \\
Oktober & 16 & Naik \\
November & 22 & Naik \\
Desember & 25 & Naik \\
Januari & 8 & Turun \\
Februari & 14 & Naik \\
Maret & 13 & Turun \\
\hline
\end{tabular}

Source: Indosat Outlet WTC, 2019

Based on the illustration in table 1.1 above, the product bundling program run by the Indosat Ooredoo Outlet with Samsung turned out to be quite successful, where the product sales volume from month to month fluctuated. 
Apart from being caused by the product bundling program, sales at Indosat WTC outlets are also influenced by several factors, including service quality, trust and customer value. Where all of this in turn is expected to be able to increase customer satisfaction.

Customer Satisfaction in the study of Imansyah \& Irawan (2018) states simply the definition of customer satisfaction is a comparison between the quality of goods or services perceived by the customer's wants, needs and expectations.

The quality of service provided by employees of the Indosat Ooredoo WTC Surabaya Store to customers plays a major role in customer satisfaction with the trust and value of customers for Samsung bundling products at the Indosat Ooredoo WTC Outlet Surabaya. Especially for loyal customers of Indosat provider users, it is clear that customers will feel the benefits obtained when these customers purchase bundling products at the Surabaya Ooredoo WTC Outlet.

Service quality according to Lubis \& Andayani (2017) is a performance that can be offered by someone to others. This performance can be in the form of actions that are intangible and do not result in ownership of any goods and to anyone. For loyal customers and customers at the WTC Indosat Ooredoo Outlet, the trust gained is the belief that service providers can use it as a tool to establish long-term relationships with customers or customers to be served. Trust is an exchange partner's willingness or confidence to establish long-term relationships to produce positive work (Putu, Pratiwi, \& Seminari, 2015). Customer value is the customer's perception of the balance between the benefits received and the sacrifices given to obtain these benefits (Saputra et al., 2018). So that it can be concluded that customer satisfaction is a comparison between the quality of goods or services perceived by the desires, needs, and expectations of customers (Imansyah \& Irawan, 2018).

Based on this background, the author is interested in raising the topic above into a study entitled "THE EFFECT OF SERVICE QUALITY, TRUST AND CUSTOMER VALUE ON CUSTOMER SATISFACTION IN INDOSAT MOVEMENT OOREDOO WTC SURABAYA (Case Study on Samsung Bundling Product Customers)."

\section{Research Objactive}

Based on the formulation of the problem above, the objectives of the research to be carried out are:

1. Analyzing the influence of service quality, trust, and customer value simultaneously on customer satisfaction Samsung bundling products at Indosat Ooredoo WTC Outlet Surabaya

2. Analyzing the influence of service quality, trust, and customer value partially on customer satisfaction Samsung bundling products at Indosat Ooredoo WTC Outlet Surabaya

\section{THEORITICAL FRAMEWORK}

\section{Service quality}

Service quality according to Kotler (2008) in Lubis \& Andayani, (2017) is a performance that someone can offer to others.

Trust

According to Tjiptono (2001: 102) in Pontoh et al., (2014) customer trust is the customer's response to the evaluation of perceived mismatch between expectations and actual performance of the product in the wearer. Customer Value

Customer value is defined as the difference in customer profits compared to costs incurred (Kotler, 2005).

\section{Customer Satisfaction}

Customer satisfaction is the level of one's feelings after comparing performance or perceived results compared to expectations (Kotler \& Keller, 2007) in Lubis \& Andayani, (2017).

\section{Previous Research}

Lubis \& Andayani (2017) The results of the study show that service quality variables, namely tangible, reliability, responsiveness, assurance and empathy, simultaneously or together have a positive and significant influence on customer satisfaction. Pontoh, Kawet, \& Tumbuan (2014). The results of this study indicate that service quality, corporate image and trust simultaneously influence customer satisfaction, partially the company's image does not significantly influence customer satisfaction while service quality and trust have a positive and significant effect on customer satisfaction. Saputra et al., (2018). The results of this study indicate that all the independent variables tested have a positive and significant effect on customer satisfaction through the $t$ test, while the Adjusted R Square number of 0.913 shows $91.3 \%$ variation in customer satisfaction PT. MPF Malang which can be explained by the two independent variables, where the remaining $8.7 \%$ is explained by other factors outside of this study. Sholeha, Djaja, \& Widodo (2018). The results showed that service quality has a 
significant influence on customer satisfaction in AHASS Sumber Jaya Maha Sakti Motor, Rogojampi District, Banyuwangi Regency. Based on this, Ho is rejected and Ha is accepted, namely 'there is a significant influence on the quality of service to customer satisfaction in AHASS Sumber Jaya Maha Sakti, Rogojampi District, Banyuwangi Regency. The results of the regression line effectiveness analysis (R2) are 79\%. This shows that the percentage effect of service quality on customer satisfaction in AHASS Sumber Jaya Maha Sakti, Rogojampi District, Banyuwangi Regency is 79\%. Putu et al., (2015). The results of the analysis obtained conclusions that the test results can be partially known the service quality, trust and value of customers berpengaruh positif dan signifikan terhadap kepuasan customers at the Dauh Ayu Savings and Loan Cooperative in Denpasar. Imansyah \& Irawan (2018) The results of this study are that there is a positive and significant effect of the quality of service on customer satisfaction at Inul Vizta Tanjung Karaoke. Winahyuningsih, (1979) The results of this study are partially trust (X1) and service quality (X2), proven to have a positive and significant effect on customer satisfaction $(\mathrm{Y})$ this is indicated by the results of the $\mathrm{t}$ test which turns out the value of $\mathrm{t}$ counts each masin $g$ variables 10.386 and 6.808 are greater than the value of t table 1.658, then $t$ count is located in the reject area (Ho), meaning that the null hypothesis (H0) is rejected and the alternative hypothesis (HA) is accepted. So all the hypotheses proposed in this study partially proved to have a significant effect on the variable customer satisfaction. Multiple variables of trust (X1) and service quality (X2) have been shown to have a significant effect on the variable customer satisfaction. This is evidenced from the results of the comparison of the values of Fcount $=203.684$ greater than $\mathrm{F}$ table $=5.18$. Kiprotich et al., (2017) The results of the study show that Customer Trust and Value have a significant effect on customer satisfaction both partially and simultaneously. Sari (2018) The results of the study show that service quality has a positive and not significant effect on customer satisfaction. The company's image has a positive but not significant impact on BSM customer satisfaction. Trust has a positive and significant impact on customer satisfaction. BSM customer satisfaction has a direct effect on customer loyalty. Service quality has a positive and significant impact on customer loyalty. The company's image has a positive and significant effect on the loyalty of BSM customers. Trust has a negative and not significant effect on customer satisfaction. Chinomona \& Sandada (2013) The results show that the relationship between customer satisfaction and their trust, customer satisfaction and their loyalty, customer trust and their loyalty, customer loyalty and their repurchase intention is positive in a significant way

\section{RESEARCH METHOD}

\section{Type of Research}

This type of research is causal research (looking for a cause and effect by using a hypothesis), where the object of this research is a case study conducted on customers at the Indosat Ooredoo WTC outlets in Surabaya. This study will use a quantitative approach, according to Sugiyono (2016) quantitative method is a scientific approach that views a reality that can be classified, concrete, observable, and measurable, the relationship of variables is causal where the research data is in the form of numbers and the analysis uses statistics. The independent variables in this study are service quality, trust, customer value and the dependent variable of customer satisfaction. The purpose of this study is more towards the results of generalizations, explaining phenomena in a more measurable manner and various evidences to be found. Data collection to obtain results of discussion, analysis and conclusions that can be accounted for.

\section{Place and Time of Research}

This research was conducted at the Indosat Ooredoo WTC Outlet Surabaya. The time of the study was conducted from March 2019 - July 2019.

\section{Conceptual Framework}

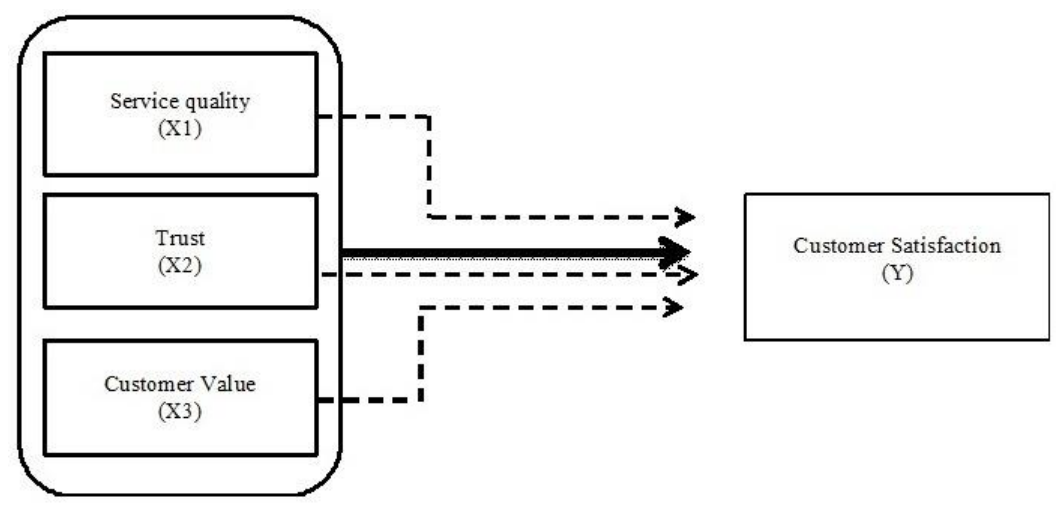


Figure 2.1 Framework for Research Concepts

\section{Keterangan :}

$$
\longrightarrow=\text { Describes the influence simultaneously }
$$

Source: Self-processed, 2019

\section{Hipotesis}

The hypothesis in this study are:

H1: Service quality has a positive and significant effect on Customer Satisfaction.

H2: Trust has a positive and significant effect on Customer Satisfaction.

H3: Customer value has a positive and significant effect on Customer Satisfaction.

H4: Service quality, trust and customer value simultaneously have a significant effect on Customer Satisfaction.

\section{Population and Sample}

The population in this study were customers who had visited, purchased and used Samsung bundling products at the Surabaya WTC Indosat Ooredoo Outlet. The sample according to Sugiyono (2013) was that the sample was part of the number and characteristics of the population. The sampling technique used is a nonprobability sampling technique precisely purposive sampling. According to Sugiyono (2013), purposive sampling is a sampling technique of data sources with certain considerations. The indicators of this study amounted to 14, the results of the sample calculation are as follows: Hair (2006) 5 or 10 times the total number of indicators. The minimum limit of respondents for this study is $14 \times 5=70$, while the maximum limit is $14 \mathrm{x}$ $10=140$. So the sample in this study amounted to 70 respondents

\section{Data Collection Method}

The data sources used in this study use primary data and secondary data. Primary data is data obtained directly from the object of research, namely customers who have visited, purchased and used Samsung bundling products at the Indosat Ooredoo WTC Outlet Surabaya. And secondary data, researchers get from data that has been processed by third parties, through books, libraries, libraries, and sources from the internet.

\section{Operational Definition of Research Variable}

\section{1) X1: Service Quality}

Service Quality is the totality of the characteristics of goods or services that show their ability to satisfy customer needs, both clearly and hidden.

\section{2) X2: trust}

customer trust is the customer's response to the evaluation of perceived mismatch between the product's actual expectations and performance in the wearer. Customer trust is a after-sales purchase evaluation where alternatives are chosen at least equal to or exceed customer expectations

\section{3) X3: customer value}

Customer value is the emotional bond that exists between the customer and the producer after the customer uses the product or service produced by the supplier and finds the product concerned adds value

\section{4) Y: Customer Satisfaction}

Customer Satisfaction is the level of one's feelings after comparing performance or results that are felt compared to expectations

\section{Data Analysis Method \\ Reliability and Validity Test}

Reliability test is a tool to measure a questionnaire which is an indicator of a questionnaire variable, declared reliable / reliable if someone's answer to a question is consistent or stable over time (Ghozali, 2013). Reliability test was carried out with the help of SPSS which is a facility to measure reliability with alpha cronbach $(\alpha)$ statistical test, a variable said to be reliable if it has cronbach alpha $>0.60$. Validity test is a measure that shows the levels of validity or validity of an instrument (Arikunto, 2012). A valid instrument has high validity, whereas an instrument that is less valid means it has a low level of validity. An instrument is said to be valid if it is able to measure what is desired and can reveal data from variables that are properly examined. The high and low validity of the meter shows the extent to which the data collected does not deviate from the description of the intended validity. Variables declared valid can be known from the significance $<0.05$ and the correlation> 0.4

\section{Multiple Regression Analysis Model}

The data analysis technique used in this study is multiple regression analysis techniques. Multiple regression analysis is used as a statistical analysis tool because this research is designed to examine the variables 
that influence the independent variables on the dependent variable. This analysis is intended to determine whether there are influences of service quality factors (X1), trust (X2), and customer value (X3) affect customer satisfaction (Y).

The formulation of the analysis model used in this study is:

$$
Y=a+b 1 . x 1+b 2 . x 2+b 3 . x 3+e
$$

Where :

$\mathrm{Y}=$ customer satisfaction

$\mathrm{a}=$ Constant

b1, b2, b3 = coefficient of determination

$\mathrm{X} 1$ = service quality

$\mathrm{X} 2$ = trust

$\mathrm{X} 3$ = customer value

$\mathrm{e}=$ Standard Error

\section{RESULT AND DISCUSSION}

\section{Result}

\section{Reliability and Validity}

The data of this study have cronbach's alpha 0.883 and are above 0.60 , so this research data can be declared reliable and reliable. all indicators used to measure service quality variables (X1), trust (X2), customer value (X3), and customer satisfaction (Y) used in this study have a correlation coefficient $>0.3$. So that all these indicators are valid

\section{Multiple Linear Regression Result}

Table 1. Multiple Linear Regression Result Coefficients $^{\text {a }}$

\begin{tabular}{|c|c|c|c|c|c|c|}
\hline \multirow{2}{*}{\multicolumn{2}{|c|}{ Model }} & \multicolumn{2}{|c|}{ Unstandardized Coefficients } & \multirow{2}{*}{$\begin{array}{c}\begin{array}{c}\text { Standardized } \\
\text { Coefficients }\end{array} \\
\text { Beta }\end{array}$} & \multirow[b]{2}{*}{$\mathrm{t}$} & \multirow[b]{2}{*}{ Sig. } \\
\hline & & B & Std. Error & & & \\
\hline \multirow[t]{4}{*}{1} & (Constant) & .628 & 1.087 & & .578 & .565 \\
\hline & Total_X1 & .177 & .054 & .262 & 3.278 & .002 \\
\hline & Total_X2 & .217 & .092 & .247 & 2.353 & .022 \\
\hline & Total_X3 & .439 & .097 & .466 & 4.547 & .000 \\
\hline
\end{tabular}

a. Dependent Variable: Total_Y

Source: SPSS Output, 2019.

Regression equation models that can be written from these results in the form of standard form regression equations are as follows:

$$
\begin{aligned}
& Y=a+b 1 \times 1+b 2 \times 2+b 3 \times 3+e \\
& Y=0.628+0.177 \times 1+0.217 \times 2+0.439 \times 3+e
\end{aligned}
$$

1. Constant Obtained Y constant value of 0.628 means that the value of customer satisfaction on Samsung bundling products at Indosat WTC Outlet Surabaya (Y) is 0.628 units if it is assumed that service quality, customer trust and value are customer satisfaction for Samsung bundling products at Indosat WTC Outlet Surabaya (Y) is 0 means if the value of the independent variable 0 then the dependent or dependent variable will be 0.628 .

2. Service quality coefficient value (X1) Service quality coefficient (X1) is 0.177 , if Indosat WTC Surabaya outlets improve service quality (X1), it will increase customer satisfaction on samsung (Y) bundling products by 0.177 units. Assuming the value of trust (X2) and customer value (X3) are zero.

3. Trust Coefficient Value (X2) Trust coefficient value (X2) is 0.217 , if Indosat WTC Surabaya Store increases trust (X2) it will increase customer satisfaction in Samsung (Y) bundling products by 0.217 units. Assuming the value of service quality (X1) and customer value (X3) equals zero

4. Value of customer value coefficient (X3) 
The coefficient value of customer value (X3) is 0.439 , if the Indosat WTC Surabaya Store increases customer value (X3), food will increase customer satisfaction on Samsung (Y) bundling products by 0.439 units. Assuming the value of service quality (X1) and trust (X2) equals zeroResult of R Square

Table 2. Result of R Square

\begin{tabular}{|c|c|c|c|c|c|}
\hline \multicolumn{6}{|c|}{ Model Summary ${ }^{b}$} \\
\hline Model & $\mathrm{R}$ & R Square & Adjusted R Square & $\begin{array}{l}\text { Std. Error of the } \\
\text { Estimate }\end{array}$ & Durbin-Watson \\
\hline 1 & $.819^{\mathrm{a}}$ & .671 & .656 & .84277 & 1.762 \\
\hline
\end{tabular}

Source: SPSS Output, 2019

Based on table 4.15 above, the coefficient $(\mathrm{R})$ indicates the significance of the influence of the independent service quality (X1), trust (X2), and customer value (X3) on the dependent variable of customer satisfaction $(\mathrm{Y})$, the coefficient value is 0.819 . This means that the independent variable of service quality (X1), trust (X2), and customer value (X3) has a strong or close influence on the dependent variable of customer satisfaction (Y).

The coefficient of determination or Adjust R Square ("R" ^ "2") is obtained at 0.656, which means the contribution of independent variables affects the dependent variable of service quality (X1), trust (X2), and customer value $(\mathrm{X} 3)$ on the dependent variable customer satisfaction (Y) of $65.6 \%$. While the remaining $34.4 \%$ is influenced by variables not examined in this study

\section{Test of Classical Assumption}

\section{1) Test ofHeteroskedastisitas}

A regression is said to detect heteroscedasticity if the residual scatter diagram forms a certain pattern. if the residual scatter diagram output does not form a certain pattern, the regression is free from the case of heteroscedasticity and meets the requirements of the classic assumption about heteroskesdastisitas (Bilondatu, 2013).

Heteroskedactivity testing charts can be explained in the following figure:

\section{Scatterplot}

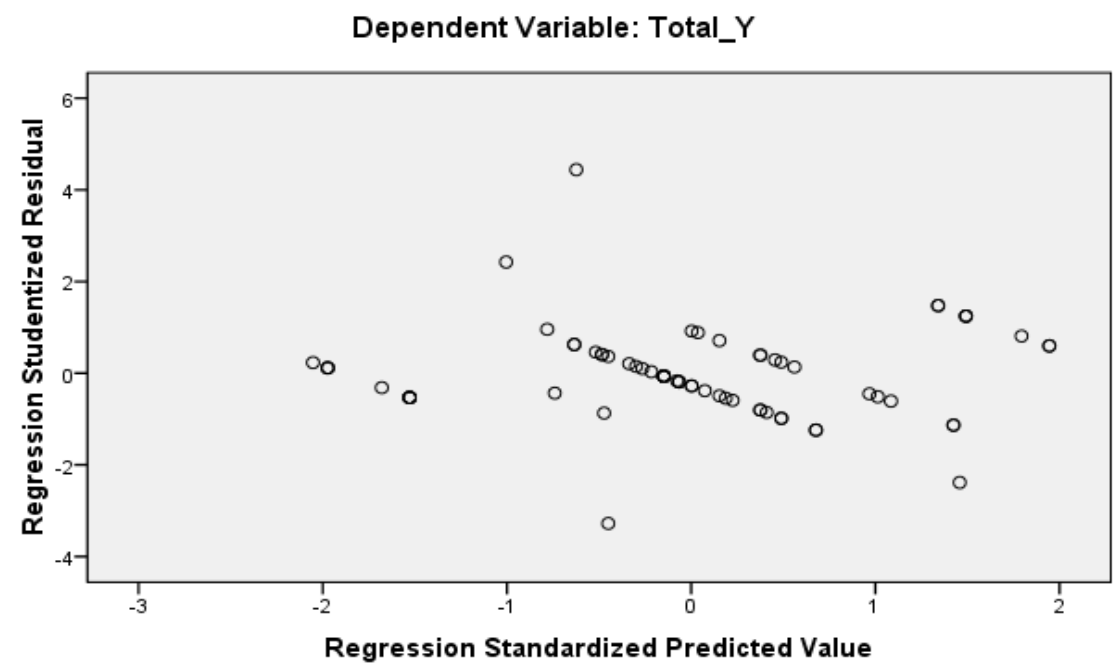

Based on the graph above, it can be seen that the distribution of data is irregular and does not form a specific pattern, and spreads above and below the number 0 on the $\mathrm{Y}$ axis, so it can be concluded that in this regression model there is no problem of heteroscedasticity 


\section{2) Uji Multikoliniearitas}

The multicollinearity test aims to test whether the regression model found a correlation between independent variables. Tolerance value calculation results show there is no independent variable that has a Tolerance value of less than 0.10 which means there is no correlation between independent variables whose value is more than 95. The calculation of the Variance Inflation Factor (VIF) value also shows the same thing there is no one independent variable has a VIF value of more than 10 . It can be concluded that there is no multicolonity between independent variables in the regression model (Bilondatu, 2013). The multicollinearity test in this study can be seen as follows.

\section{Tabel 4.18 Uji Multikoliniearitas}

\section{Coefficients $^{\mathrm{a}}$}

\begin{tabular}{|ll|r|r|}
\hline \multirow{2}{*}{ Model } & & \multicolumn{2}{|c|}{ Collinearity Statistics } \\
\cline { 3 - 4 } & & Tolerance & \multicolumn{1}{c|}{ VIF } \\
\hline 1 & (Constant) & & \\
& Total_X1 & .778 & 1.285 \\
& Total_X2 & .454 & 2.202 \\
& Total_X3 & .476 & 2.101 \\
\hline
\end{tabular}

a. Dependent Variable: Total_Y

Sumber : Data Output SPSS

Based on Table 4.18 it can be seen that the regression model does not experience multicollinearity disorders. This can be seen in the tolerance value of each independent variable greater than 0.1. The VIF calculation results also show that the VIF value of each independent variable is less than 10 . So it can be concluded that there is no multicollinearity between the independent variables in the regression model.

\section{Uji Normalitas}

Normality test is intended to find out whether the residuals studied are normally distributed or not. This test is used to determine whether a regression model, independent variables, dependent variables, or both have a normal distribution or not. In this test using a graphical approach, namely the P-P Normal graph Plot of regression standard, with this test it is required that the distribution of research data must follow a diagonal line between 0 and the $\mathrm{X}$ and $\mathrm{Y}$ axis meetings.

\section{Gambar Hasil Perhitungan Uji Normalitas}

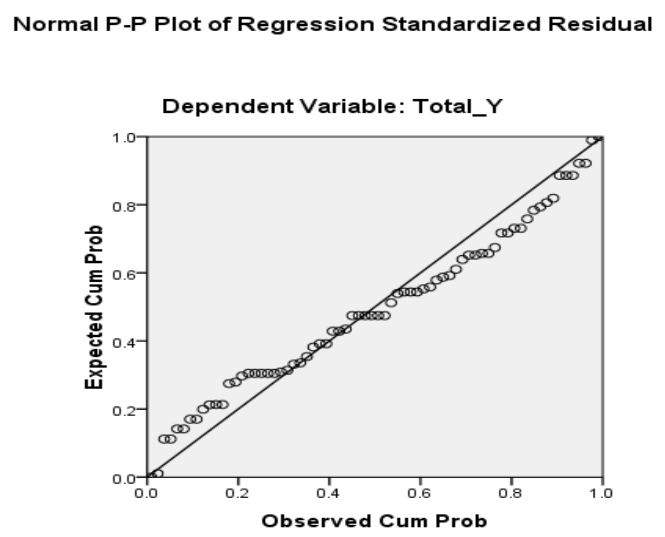

Source: SPSS Output Data

Based on the graph above shows that all existing data are normally distributed, because all data spreads form a diagonal straight line so that the data meets the normal assumptions or follows the normality line.

\section{Hypothesis Testing F-Test}


The F-test is used to determine all effects of all independent variables on the dependent variable. This test is done by comparing the Fcount value with Ftable value at $\alpha=0.05$.

Tabel 4. Hasil Uji-F

ANOVA $^{b}$

\begin{tabular}{|ll|r|r|r|r|r|}
\hline Model & & Sum of Squares & df & Mean Square & F & \multicolumn{1}{c|}{ Sig. } \\
\hline 1 & Regression & 95.466 & 3 & 31.822 & 44.803 & $.000^{\mathrm{a}}$ \\
& Residual & 46.877 & 66 & .710 & & \\
& Total & 142.343 & 69 & & & \\
\hline
\end{tabular}

a. Predictors: (Constant), Total_X3, Total_X1, Total_X2

b. Dependent Variable: Total_Y

Sumber : Data Output SPSS

The results of the $\mathrm{F}$ test calculation obtained results $\mathrm{F}$ count 44.803 greater $\mathrm{F}$ table 2.74 with a sign level of 0.000 smaller $(\alpha) 0.05$, because the probability is smaller 0.05 then H0 is rejected and Ha is accepted. Thus the hypothesis that states service quality, trust and customer value simultaneously have a significant positive effect on customer satisfaction is proven empirically.

\section{T-Test}

Table 5. T-Test Result Coefficients $^{\mathrm{a}}$

\begin{tabular}{|c|c|c|c|c|c|c|}
\hline \multirow{2}{*}{\multicolumn{2}{|c|}{ Model }} & \multicolumn{2}{|c|}{ Unstandardized Coefficients } & \multirow{2}{*}{$\begin{array}{c}\begin{array}{c}\text { Standardized } \\
\text { Coefficients }\end{array} \\
\text { Beta }\end{array}$} & \multirow[b]{2}{*}{$\mathrm{t}$} & \multirow[b]{2}{*}{ Sig. } \\
\hline & & B & Std. Error & & & \\
\hline \multirow[t]{4}{*}{1} & (Constant) & .628 & 1.087 & & .578 & .565 \\
\hline & Total_X1 & .177 & .054 & .262 & 3.278 & .002 \\
\hline & Total_X2 & .217 & .092 & .247 & 2.353 & .022 \\
\hline & Total_X3 & .439 & .097 & .466 & 4.547 & .000 \\
\hline
\end{tabular}

a. Dependent Variable: Total_Y

Source: SPSS Output, 2019

Based on table 4.19 Test T obtained the results of partial hypothesis testing as follows:

Effect of service quality variable (X1) on customer satisfaction (Y) Analysis of service quality variables (X1) is obtained by the value "t" _ "count" of 3.278 and the value of " $t$ " _ "table" is 1,996 with a significant value of 0.002 (more small than 0.05 ) which means the service quality variable (X1) has a significant influence on customer satisfaction $(\mathrm{Y})$.

The influence of trust variable (X2) on customer satisfaction (Y) The results of the analysis of the trust variable (X2) obtained the value " $t$ " - "count" of 2,353 and the value " $t$ " - "table" amounted to 1,996 with a significant value of 0.022 (smaller than 0.05 ) which means the trust variable (X2) has a significant influence on customer satisfaction (Y).

Effect of customer value variable (X3) on customer satisfaction (Y) The results of analyzing the customer value variable (X3) obtained the value " $t$ " - "count" of 4,547 and the value " $t$ " - "table" is 1,996 with a significant value of 0,000 (more small than 0.05 ) which means the customer value variable (X3) has a significant influence on customer satisfaction (Y)

\section{DISCUSSION}

A. Effect of Service Quality on Customer Satisfaction

Partially, there is a positive and significant influence on service quality variables on customer satisfaction.

Service quality is closely related to customer perceptions about the quality of a business. The better service provided will affect the level of satisfaction that customers feel so that the business will be considered more qualified. Conversely, if the services provided are not good and satisfying, then the business is also considered to be of poor quality. Therefore, efforts to improve service quality must continue to be carried out in order to maximize the quality of services. So that the better the quality of service provided to customers, the higher the customer satisfaction on the quality of service that has been provided 
B. Effect of Trust in Customer Satisfaction

Secara parsial menunjukkan adanya pengaruh yang positif dan signifikan pada variabel kepercayaan terhadap kepuasan konsumen.

The trust given by customers to a product or service provided by a particular company is closely related to customer satisfaction, especially in the research that the author took at the Indosat WTC Outlet, where customers at the Outlet are loyal customers of Indosat products in the form of prepaid and postpaid especially with the presence of Samsung bundling products at the outlet

C. Effect of Customer Values on Customer Satisfaction

Partially, there is a positive and significant influence on customer value variables on customer satisfaction. This means that the better the customer value is believed to affect the better customer satisfaction

\section{Conclusion}

\section{CONCLUSION AND RECOMMENDATION}

Based on the results of the research and analysis that has been done can be stated several things which are the conclusions of this study, namely:

The conclusions of this study are:

1. Partially the independent variable of service quality influences customer satisfaction of Samsung bundling products in the Indosat Ooredoo WTC Outlet Surabaya.

2. Partially, the independent variable of customer value influences customer satisfaction of Samsung bundling products in the Indosat Ooredoo WTC Outlet Surabaya.

3. Simultaneously the three independent variables of service quality, trust, and customer value have a positive effect on customer satisfaction of Samsung bundling products in the Indosat Ooredoo WTC Outlet Surabaya.

4. From the results of the determination test obtained the coefficient of determination or Adjust R Square ("R" ^ "2") obtained at 0.656 , which means the magnitude of the contribution of independent variables affect the dependent variable service quality (X1), trust (X2), and customer value ( X3) to the dependent variable of customer satisfaction $(\mathrm{Y})$ of $65.6 \%$. While the remaining $34.4 \%$ is influenced by variables not examined in this study.

\section{Recommendation} Suggestions from this study are:

1. Indosat Ooredoo outlets are expected to pay more attention and make it easier for customers who want to submit complaints - complaints that are felt by customers.

2. To increase trust, Indosat Ooredoo outlets must be able to prioritize the interests and meet the needs of customers quickly.

3. It is better if Samsung in Indosat Ooredoo outlets can provide products that are not yet available, so that it does not make customers think of switching to another provider

4. For further researchers it is expected to develop this research with variables that have not been studied in this study such as product quality and price.

\section{REFERENCES}

Ari, O., Wibowo, S., \& Manajemen, J. (2013). PENGARUH HARGA, KUALITAS PELAYANAN DAN NILAI PELANGGAN TERHADAP KEPUASAN KONSUMEN PADA RUMAH MAKAN DI KOTA PURWOKERTO SKRIPSI Untuk Memperoleh Gelar Sarjana Ekonomi Pada Universitas Negeri Semarang.

Arikunto, S. (2012). Prosedur Penelitian Suatu Pendekatan Praktek. Jakarta: Rineka Cipta.

Chinomona, R., \& Sandada, M. (2013). Customer Satisfaction, Trust and Loyalty as Predictors of Customer Intention to Re-Purchase South African Retailing Industry. Mediterranean Journal of Social Sciences, 4(14), 437-446. https://doi.org/10.5901/mjss.2013.v4n14p437

Darwin, S., \& Sondang Kunto, Y. (2014). Program Manajemen Pemasaran, Universitas Kristen Petra Jl. Siwalankerto 121-131, Surabaya. Analisis Pengaruh Kualitas Layanan Terhadap Loyalitas Pelanggan Dengan Kepuasan Dan Kepercayaan Pelanggan Sebagai Variabel Intervening Pada Asuransi Jiwa Manulife Indonesia - Surabaya, 2(1), 1.

Ghozali, I. (2013). Aplikasi Analisis Multivariate dengan program SPSS (7th ed.). Semarang: Badan Penerbit Universitas Diponegoro.

Hair, J. . (2006). Multivariate Data Analysis (5th ed.). Jakarta: Gramedia Pustaka Utama.

Imansyah, \& Irawan, H. (2018). Pengaruh Kualitas Pelayanan Terhadap Kepuasan Pelanggan Pada Karaoke Inul 
Vizta Tanjung. Jurnal Ilmiah Ekonomi Bisnis, 4(3), 319-329.

Kiprotich, H., Elizabeth Nambuswa, M., Gregory, N., Gregory, N., \& Author, C. (2017). Factors Influencing Non-Performing Loans in Registered Savings and Credit CoOperative Societies in Kenya: A Case of Trans Elite County Sacco in Nandi County. Saudi Journal of Business and Management Studies, 2(5), 507-512. https://doi.org/10.21276/sjbms

Lubis, A. S., \& Andayani, N. R. (2017). Pengaruh Kualitas Pelayanan ( Service Quality ) Terhadap Kepuasan Pelanggan Pt . Sucofindo Batam. Journal of Business Administration, 1(2), 86-97.

Pontoh, M. B., Kawet, L., \& Tumbuan, W. A. (2014). Kualitas Pelayanan, Citra Perusahaan dan Kepercayaan Pengaruhnya terhadap Kepuasan Nasabah Bank BRI Cabang Manado. Jurnal EMBA, 2(3), 285-297.

Prakoso, A. A. (2017). ANALISIS PENGARUH KEPERCAYAAN, KUALITAS PELAYANAN, DAN HARGA TERHADAP KEPUASAN PELANGGAN SERTA DAMPAKNYA PADA LOYALITAS (Studi Pada Forum Jual Beli Kaskus).

Putu, N., Pratiwi, L., \& Seminari, N. K. (2015). Pengaruh Kualitas Pelayanan, Kepercayaan Dan Nilai Nasabah Terhadap Kepuasan Nasabah. E-Jurnal Mananjemen Unud, 4(5), 1422-1433.

Saputra, A. D., Manajemen, P. S., Tinggi, S., Ekonomi, I., Malang, K., Pelanggan, K., \& Pelayanan, K. (2018). Pengaruh Kualitas Layanan dan Nilai Pelanggan Terhadap Kepuasan Pelanggan PT . Millenium Penata Futures Malang. 1, 75-85.

Sari, N. (2018). Service Quality, Company Image, Trust and Its Influence On Customers' Satisfaction and Loyalty at Bank Shariah Mandiri (BSM) Meulaboh Branch Office. Jurnal Ilmiah Peuradeun, 6(2), 235. https://doi.org/10.26811/peuradeun.v6i2.221

Sholeha, L., Djaja, S., \& Widodo, J. (2018). Pengaruh Kualitas Pelayanan Terhadap Kepuasan Pelanggan Di Ahass Sumber Jaya Maha Sakti Kecamatan Rogojampi Kabupaten Banyuwangi. JURNAL PENDIDIKAN EKONOMI: Jurnal Ilmiah Ilmu Pendidikan, Ilmu Ekonomi Dan Ilmu Sosial, 12(1), 15. https://doi.org/10.19184/jpe.v12i1.6465

Sugiyono. (2013). Metodelogi Penelitian Kuantitatif, Kualitatif Dan R\&D. Bandung: ALFABETA.

Winahyuningsih, P. (1979). Pengaruh kepercayaan dan kualitas pelayanan terhadap kepuasan konsumen pada hotel griptha kudus. Ekonomi Bisnis, 1-17. 